\author{
S. L. Nikiforov · Yu A. Pavlidis · V. Rachold \\ M. N. Grigoryev · F. M. Rivkin · N. V. Ivanova \\ M. M. Koreisha
}

\title{
Morphogenetic classification of the Arctic coastal zone
}

Received: 5 December 2003 / Accepted: 2 August 2004/Published online: 3 December 2004

(C) Springer-Verlag 2004

\begin{abstract}
Arctic coastal evolution is the result of interactions between exogenic and endogenic processes. In the arctic region, this evolution differs from that in other areas of the world's oceans as a result of interactions between modern wave and ice factors, and the influences of glaciations and large-scale sea level changes in the past. Geologic structure, origin and development determine contemporary relief morphology. Morphology appears to be the most significant relief characteristic, but it is controlled by a set of interactive processes active over long periods. Our approach, in which a multitude of interacting factors are simultaneously analyzed and determined, could be called "morphogenetic". We consider marine coasts and offshore zones (shelf) as a unit, and providing a general explanation for their evolution. The classification presented here is based upon the general approach given in the Science and Implementation Plan of Arctic Coastal Dynamics (ACD), a project of the International Arctic Science Committee and the International Permafrost Association. Our classification extends beyond the morphological ACD classification to include a morphogenetic classification.
\end{abstract}

S. L. Nikiforov $(\bowtie) \cdot$ Y. A. Pavlidis

P.P.Shirshov Institute of Oceanology RAS,

Nahimovsky prospect, 36, Moscow, Russia

E-mail: nikiforov@geo.sio.rssi.ru

Tel.: + 7-095-1248702

Fax: + 7-095-1248702

V. Rachold

Alfred Wegener Institute for Polar and Marine Research,

Research Unit Potsdam, Germany

M. N. Grigoryev

Permafrost Institute, Russian Academy of Sciences,

Siberian Branch, Yakutsk,

F. M. Rivkin · N. V. Ivanova · M. M. Koreisha Institute of Engineering Survey for Construction, Industrial and Research, Moscow, Russia

\section{Introduction}

The classification presented here is based on scientifically proven representations of morphology, origin and age as well as the geological and neotectonic provenance of coasts and seabed relief. This kind of approach, in which a multitude of interacting factors are simultaneously analyzed and determined, could be called "morphogenetic".

We define the coastal zone as "extending from the coastal plains to the outer edge of the continental shelves, approximately matching the region that has been alternately flooded and exposed during the sea level fluctuation of the Late Quaternary period", following the LOICZ Project definition (Coastal Zone Resources Assessment Guidelines 1996). Under "coasts" we understand an "onshore and coastal shallow that has been alternately flooded and exposed since middle Holocene time (climatic optimum)."

The proposed classification develops the Science and Implementation Plan of Arctic Coastal Dynamics (ACD) project approach. Morphology remains the most significant relief characteristic as per the ACD classification. However, relief morphology does not appear steady and changes with time. Analogous changes took place in the past, occur in the present and will continue in the future. As a result of climate warming, changes in relief morphology will be more active than at the present time. The main cause of changes lies in the fact that natural processes determine relief morphology and should be regarded together with relief morphology. In our classification, we attempt to distinguish the dominant natural process that resulted in the relief formation and its changes in the past and in the present. Some of the natural processes will intensify in the future, while others will moderate. In the context of such an approach, it is possible to ascertain future trends of relief morphology change. For instance, wave action during coastal formation, with intensification of abrasive processes, is currently increasing. As a result, the total ex- 
tent of the abrasion sections of Arctic coast exceeds the length of the accumulation sections.

Knowledge of natural relief-forming processes is an important link in the system "land-ocean interaction", and must be taken into consideration in research of any scale. Indissoluble connections between natural processes and relief morphology exist. This connection is always observed: in research at larger scales for issues such as hazard assessment, climate change, etc., and within the framework of detailed analyses, including work in the context of the ACD project (coastal segmentation). This approach is an integral part of the ACD project for which there are indications that natural processes play a great role. In particular, ACD aims "to identify and understand the key processes controlling Arctic coastal dynamics and their impact on human systems, biology and ecosystems" and "to establish models to predict the future behavior of the Arctic coastal zone in response to climate and sea-level changes" (Rachold et al. 2003). Within the framework of the ACD Workshops, the coastal dynamics as a function of environmental forcing is constantly accentuated.

We regard marine coasts and the offshore zone (shelf) as a unit and provide a general model for their evolution. Accordingly, the principles of classification are the same for both regions.

The seabed is characterized by the predominance of the contemporary accumulative processes connected mainly to the processes of suspended load precipitation (normal sedimentation). These processes are controlled by currents, circular eddies, and extreme storms. Sedimentation under the ice in heavily glaciated regions (vast areas of the East Siberian Sea) plays an important role. The seabed surface is rather static with the exception of that of the Gorlo of the White Sea, Gorlo Cheshskoy Gyby and others, where the tidal flows are considerable. These processes play a less important role in relief formation in straits and in large estuaries.

\section{Background, materials and methods}

Earlier attempts at coastal classification had considerable gaps, since many forms and types of relief were not described and morphological features were emphasized. One of the first classifications, made by Richthofen (1901), is purely based on the morphology of the inner shelf. The most detailed classification was created by Schlüter (1924), in which he analyzed the peculiarities of the last (post glacial) sea level uplift in different geological situations in the context of the influence of climatic factors and high tides on coastal shaping in various zones of the world's oceans. In the second part of the previous century, several marine coast classifications were developed by Valentin (1952), Zenkovich (1954), Leont'ev (1956), McGill (1959), Ionin et al. (1961), Leont'ev et al. (1975), and Kaplin et al. (1991). A common disadvantage of the listed classifications is the high degree of generality, and all were intended for small scale mapping only. The variety of modern and paleogeographical processes in the Arctic are not reflected in these classifications, despite the fact that these processes distinguish the Arctic from other climatic zones. Furthermore, Arctic coasts and offshore zones were not analyzed as a unit, so that their regional peculiarities were not described in full measure, and their complicated history of development and the specific character of the dominant relief-forming processes were neglected.

At the same time "coastal zone" is interpreted as "extending from the coastal plains to the outer edge of the continental shelves, approximately matching the region that has been alternately flooded and exposed during the sea level fluctuation of the Late Quaternary period" (Coastal Zone Resources Assessment Guidelines 1996). This implies the necessity of a unified classification of the sea floor forms and the coast types based on uniform principles. In the classification presented here take into account processes and factors determining the type of sea coast as well as the morphology of relief forms. In addition, the evolutionary history was observed. It is stated that the development of the coastal zone in the Late Quaternary period was affected by the large-scale sea level fluctuations, which resulted in coastline migration along the shelf profile. Many forms of relief currently located below sea level, on the shelf, are genetically determined by the processes of coastal formation.

The morphogenetic approach enables us to accommodate the wide complex of interacting factors that simultaneously determine both the origin and morphology of different coastal relief forms.

The first and unique attempt at shelf form classification on the basis of morphogenetic principles was made by Ionin et al. (1990) more than 10 years ago. The role of the key relief-forming active and passive factors and processes, often in their complex interaction, was assumed as a principle. However, this classification disregards regional features of Arctic shelf relief formation. The proposed classification reworks the previous approaches with reference to the Arctic shelves.

The ACD project is a milestone in the preparation of such a classification. We have made an attempt to broaden the morphologic ACD classification and to bring morphologic relief characteristics in agreement with their genetic adjunct. That complies with the ACD project principles, which interpret coastal dynamics as a function of environmental forcing. This classification of the Arctic coastal zone that includes Arctic coasts and the seabed is based on long-term investigations.

In different years, our detailed multidisciplinary coastal investigations were conducted in the White Sea and on the Kola Peninsula, including the Barents coastal zone, in the fiords of Novaya Zemlya, in the Pechora and Kara seas, on the western coast of Yamal and in Baidaratskaya Guba, on Taimir Peninsula, along the Anabara-Olenek watershed coasts, in Olenek Bay and on the Lena Delta coasts, in Buor-Khaya Bay, on the island of Muostakh, on the New Siberian Islands coasts, in 
Dmitry Laptev Strait, Kolyma Bay, and on the EastSiberian and Chukchy coastal zone. Investigations of the coasts were conducted both offshore and in coastal shallows, including inshore lagoons (Grigoriev et al. 2003; Rachold 1999, 2000; Rachold and Grigoriev 2001).

The main methods of onshore coastal studies are: (1) reviewing and reworking of both existing publishing and our own data; (2) field studies (the description of coastal relief morphology, measurement of coastal dynamics parameters as well as the investigation and sampling of geological and geocryological peculiarities of onshore outcrops); (3) processing and analysis of remote sensing material on the coastal zone (topographic and special thematic maps, satellite images and aerial photographs from different years). We use hydrometeorological observations, including measurements of wind and wave characteristics, as well as air and seawater temperatures (from the surface to the bottom) at the key sites.

Investigations in the offshore zone were conducted mainly on research vessels of small displacement, such as the "Professor Shtockman", the hydrographic vessels "Dmitry Laptev", "Maligin", "Vega", "Dunay", "Smirnitsky", and others. The bigger ships such as "Academic Sergei Vavilov", "Dmitriy Mendeleev", the icebreaker "Georgiy Sedov" and others (anchor stations and profiles on boats nearby) were used with modern instrumentation, including narrow-beam and multi-beam echo sounders, the "Parasound" profilograph, lateral view locators and samplers of different systems. During the last 5 years, detail field coastal studies within the framework of Russian-German expeditions were also conducted.

Details of much of this data collecting are available in the following cruise reports: White Sea (1962, 1964, 1965); Chukchy Sea (hydrographic vessels "Dmitiy Laptev" and "Maligin"-1978, 1981); East Siberian Sea (ice-breaker "Georgiy Sedov"-1981), Barents and Kara Seas - (eighth, tenth, 12th, 19th cruises of $\mathrm{r} / \mathrm{v}$ "Professor Shtockman"-1982, 1983, 1984, 1988); Kara Sea (41th cruise of r/v "Dmitriy Mendeleev"-1993); the Pechora Sea (13th cruise of $\mathrm{r} / \mathrm{v}$ "Academic Sergey Vavilov"-1998). All of the listed cruise reports are available from the Shirshov Institute of Oceanology (IORAS) in Moscow.

\section{Results and discussion}

The Arctic coastal zone occupies a special place in the world's oceans. The climate strongly affects not only the character of modern coast-forming processes but also mobilization, transfer, and sedimentation in the coastal zone. Initial structures form the basement surface that has been reworked, or is now being reworked, by a complex of environmental processes. Among exogenic and endogenic processes it is possible to identify active processes, directly participating in the formation of coastal relief, and passive processes, which predetermine the display of active ones and direct a course for their development.

This work attempts to develop the concept that the origin of the relief (formed under the interaction and combination of various modern and paleogeographical processes jointly with geological provenance) was the most important factor in creating extant coastal morphology.

Morphological coast types could be characterized as landscapes that form under a unique combination of modern, paleogeographical and geological conditions (Table 1). Coast types are composed by the combination of forms of relief from a sequence of modest length. Such a combination of coastal forms determines the general appearance of each coast type and reflects the interaction of the main relief processes that, due to coast type, currently exist. For instance, the coast type, "fiord", is, in fact, rather a long coastal area within which occur a number of different coastal relief forms, such as: cliffs unchanged by the sea, abrasion-denudation coasts, ice coast, moraine taluses, etc. These combinations of coastal forms lend the fiord landscape its unique appearance. Depending on their specific origin and evolution, coast types are characterized by their own combination of coastal relief forms.

Specific coast types arise from the main relief processes that take part in their formation. For example, the coast type "fiord" was mainly created under tectonics jointly with ice exaration and erosion processes. The coast type "accumulative with lagoons" arose via wave processes during recent (Late Pleistocene-Holocene) sea level uplifting and via modern processes (other types have had polygenetic origin).

Dominant relief processes and their development are the result of interactions between endogenic and exogenic processes. In any particular situation we could determine the dominant factor governing coast formation. These dominant factors could be (1) structural (endogenic), (2) structural-sculptural (endogenic-exogenic), and (3) sculptural (exogenic) (Table 1).

The classification presented here is based on the general approach given in the ACD, which is a project of the International Arctic Science Committee and the International Permafrost Association (IASC Arctic Coastal Dynamics 2001). However, in addition to the morphological classification suggested by the ACD project, the classification suggested in this present paper considers interactions between coastal morphology and dominant factors (processes) governing coast formation. For example, within the framework of the ACD project, studies of detailed morphological characteristics of coastal sections have been carried out. At present, a distinction has been made for abrasive-cryogenic coasts of the Laptev Sea, which, in our classification, appear as a unique coast type from a genetic point of view. We hold that the combination of major morphological features justify a classification of abrasive-cryogenic coasts in general and of coastal relief forms in particular. The coastal gradations listed in Table 1 could be expanded 


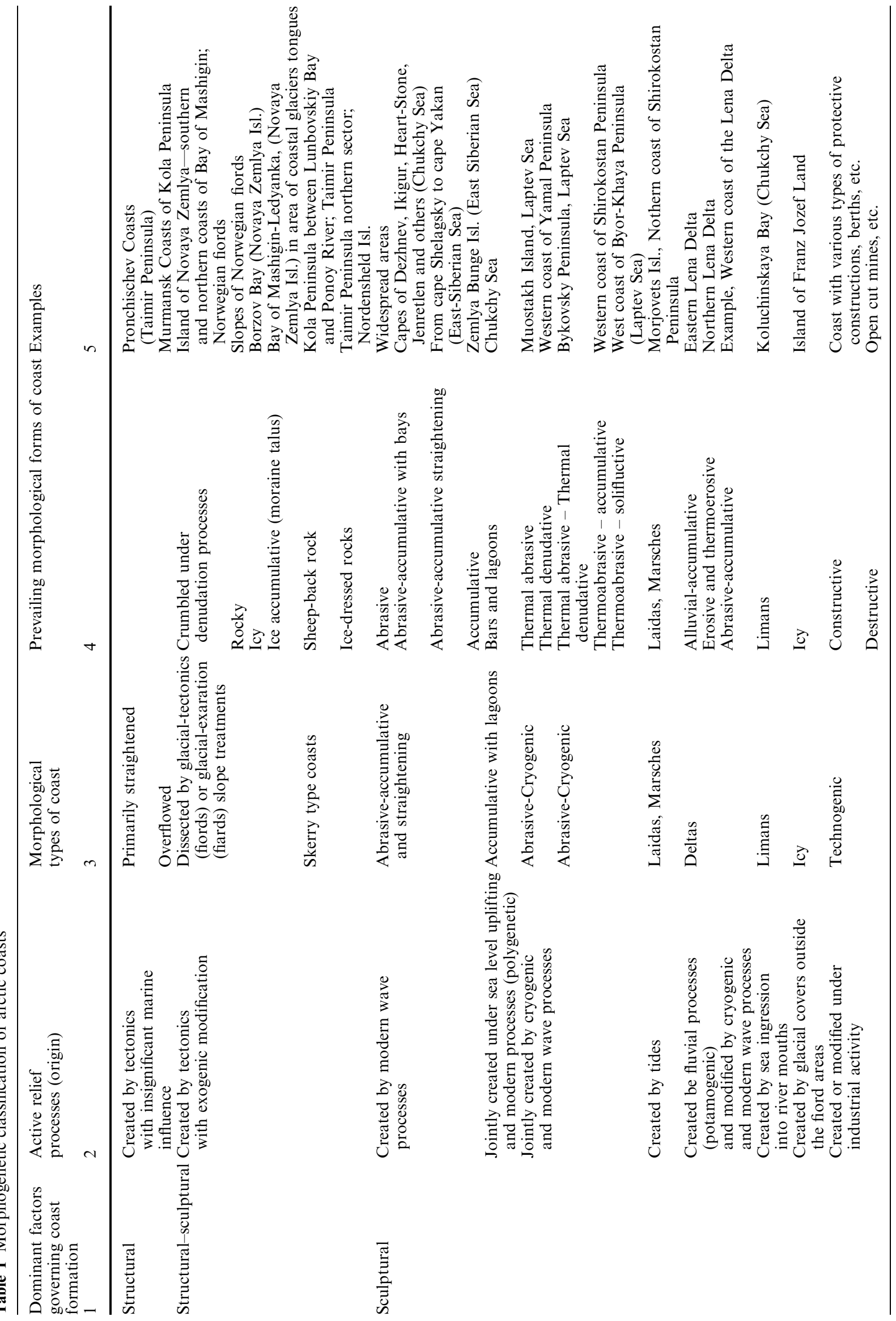


through the addition of detailed morphological characteristics of coastal relief forms (cliff height, beach width, etc.). These data could be reflected as a separate column in the table. Morphological parameters identified in the ACD Project, including onshore, backshore, frontshore and offshore zone (Table 2) parameters, could be listed in these additional columns. The presented classification permits mapping at different scales. Mapping at a smaller scale could consider morphological coast type characteristics only (such as: fiord or fiard-type shoreline, lagoon-type coast, etc.). On the other hand, the classification could be expanded by additional data through continued subdivision of gradations.

The engineering-geocryological zonation of the Arctic coast could be integrated into this classification system as well. One of the major goals of zoning is an assessment of the intensity of exogenous geological processes along the Arctic coast. This assessment is a basis for the assessment of hazards for industrial activity on the Arctic coast (construction of pipelines, oil and gas terminals, etc.). The Arctic coastal zoning enables one to associate the major morphogenetic coastal types as classified here with the main varieties of rocks composing the coast (Table 3 ).

The methodological basis of Arctic coastal zoning consists of: (1) the generalization of major coastal types selected from the morphogenetic classification; (2) their correlation with modern engineering-geocryological conditions on the Arctic coast; (3) a detailed segmentation of the Arctic coast.

We generalized three main morphogenetic coastal relief forms at a scale of 1:8,000,000: abrasive, accumulative, and stable (Table 3). Most of the coast is composed of frozen, scattered rocks. Their transformation by the sea and by exogenous geological processes depends to a significant extent on their ice content (low ice content, moderate ice content, or ice-rich). In addition, 26 engineering-geological regions were identified. The tables listing these zones is, in fact, a legend to the Arctic coastal zoning map at a scale of $1: 8,000,000$ (Rivkin et al. 2003).

The main principles of coastal morphogenetic classification correspond to the principles of the morphogenetic classification of Arctic coastal offshore zones. Using the same approach, we identified three broad categories of seabed relief: structural, structural-sculptural and sculptural. Such a division is rather relative in some cases. We understand that the offshore zone forms under the joint influence of endogenic and exogenic processes. Extensive marine studies are required to include seabed relief. It is necessary to determine the dominant factor governing seabed formation.

We also allocated structural and sculptural relief and its morphogenetic divisions somewhat subjectively. For example, geologists usually try to examine existing seabed relief from structural provenance only while specialists in paleogeography and modern processes, on the other hand, consider seabed origin mainly in association with exogenic processes.

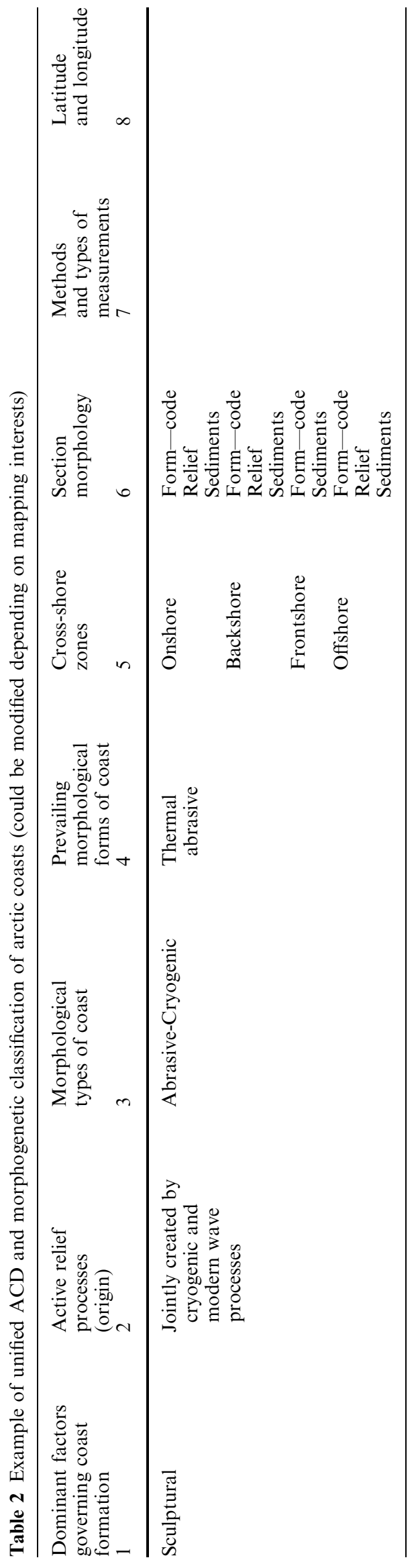


Table 3 Engineering-geological zoning of the Arctic coast

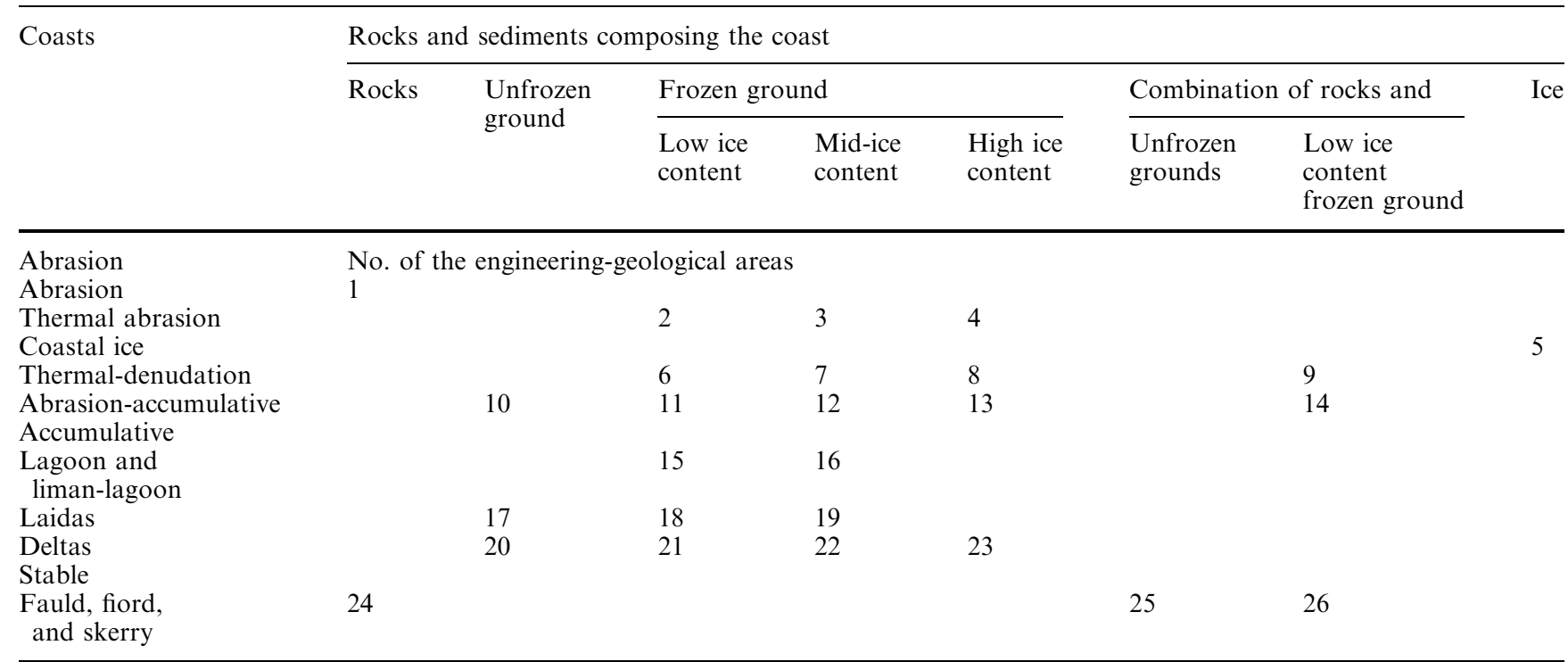

We have tried to analyze all interacting factors with minimal bias. From this point of view, it is better to create seabed characteristics in a "layer by layer" fashion. For example, four layers might be created thus: bathymetry; endogenic background; relief connected with the action of paleogeographic factors; relief caused by the action of modern processes. The necessity of a "layer by layer" method for assembling relief characteristics arises inevitably from the creation of such specialized maps (geomorphological, etc.). For example, if we combine bathymetry (first layer), geology (second), paleogeography (third) and modern processes (as the last layer), we create a geomorphological map. Using this combination, it becomes possible to create other maps and schemes.

Turning back to our classification, we treat almost all structural forms as large seabed forms, predetermined by geological structures and created by endogenic processes (i.e. by folded and fault-fracture tectonics, displays of the most recent differential vertical movements of the earth's crust and so on). Geological struc- tures underlay practically all forms of seabed relief and determine the positions of its large forms. Relief created under the domination of tectonics could be divided into several types generated within anticlines and brachyanticlines, synclines and brachysynclines, monoclines and flexures, faults and fault-blocks (graben valleys), horsts and fracture-block zones (Table 4).

Structural-sculptural relief refers to a category of transient and in some cases relict formations. These relief could be divided into: (1) large troughs frequent with "stairs" of inset erosive-accumulative terraces created by paleo-flows into large structural valleys; (2) landslides, blocks and ridges near to the shelf edge and on the continental slope, swells in the coastal zone, landslide cones and cirques within canyons, fiords and depressions, created by gravitation processes on steep structural slopes; and (3) fiords and underwater trough valleys continuing them created by tectonics with exogenic modification (Table 5).

The sculptural relief of the Arctic seabed could be divided into several types too, which are listed in Table 6.

Table 4 Structural coastal seabed relief created under dominance of tectonics

\begin{tabular}{|c|c|}
\hline $\begin{array}{l}\text { Active relief processes (origin) } \\
1\end{array}$ & $\begin{array}{l}\text { Types and forms of seabed relie } \\
2\end{array}$ \\
\hline $\begin{array}{l}\text { Created by tectonics within anticlines } \\
\text { and brachyanticlines }\end{array}$ & $\begin{array}{l}\text { Raisings-islands, the } \\
\text { shallow banks, the extended } \\
\text { ridges and swells }\end{array}$ \\
\hline $\begin{array}{l}\text { Created by tectonics within synclines } \\
\text { and brachysynclines }\end{array}$ & $\begin{array}{l}\text { Extended troughs, depressions } \\
\text { and shallow depressions }\end{array}$ \\
\hline $\begin{array}{l}\text { Created by tectonics within monoclines } \\
\text { and flexures }\end{array}$ & Extensive horizontal plains \\
\hline $\begin{array}{l}\text { Created by tectonics within faults } \\
\text { and fault-blocks (graben valleys) }\end{array}$ & $\begin{array}{l}\text { Graben valleys, inter-island } \\
\text { channels }\end{array}$ \\
\hline Created by tectonics within horsts & $\begin{array}{l}\text { Underwater elevations, } \\
\text { separate islands as } \\
\text { "Farewell Rock", }\end{array}$ \\
\hline
\end{tabular}

Natural examples, regions of distribution

Franz Josef Land archipelagos, Wrangel Island, Gusinaya bank in the Barents Sea, Gerald bank in the Chukchy Sea

Long Strait, the Central-Chukchy depression,

Southern Barents Sea depression

Part of the Kara Sea shelf to the north of $\mathrm{Ob}$ and Yenisey estuaries

Medvezhinskij, Franz Victoria, George,

St. Anna, Voronin, Sedov troughs

Structural-block raisings (Murmansk, Central, Persey), overfault-block raising of Gusinaya bank in Barents Sea 
Table 5 The structural - sculptural coastal seabed relief created under dominance of tectonics and exogenic processes

\begin{tabular}{|c|c|c|}
\hline $\begin{array}{l}\text { Active relief processes (origin) } \\
1\end{array}$ & $\begin{array}{l}\text { Types and forms of seabed relief } \\
2\end{array}$ & $\begin{array}{l}\text { Natural examples, regions of distribution } \\
3\end{array}$ \\
\hline $\begin{array}{l}\text { Created by paleo flows into } \\
\text { large structural valleys }\end{array}$ & $\begin{array}{l}\text { Large troughs, frequently } \\
\text { with "stairs" of inset } \\
\text { erosive-accumulative terraces }\end{array}$ & Chukchy Trough \\
\hline $\begin{array}{l}\text { Created by gravitation processes } \\
\text { on steep structural slopes }\end{array}$ & $\begin{array}{l}\text { Landslides, blocks and ridges } \\
\text { near to shelf edge and on } \\
\text { continental slopes, swells in } \\
\text { coastal zones, landslide cones } \\
\text { and circuses within canyons, } \\
\text { fiords and depressions }\end{array}$ & $\begin{array}{l}\text { Fiords of the Northern Norway } \\
\text { and Novaya Zemlya Isl., } \\
\text { Beaufort Sea canyons }\end{array}$ \\
\hline $\begin{array}{l}\text { Created by tectonics with } \\
\text { exogenic modification }\end{array}$ & $\begin{array}{l}\text { Fiords and underwater trough } \\
\text { valleys continuing them }\end{array}$ & $\begin{array}{l}\text { Fiords of Northern Norway, } \\
\text { Novaya Zemlya Isl. }\end{array}$ \\
\hline
\end{tabular}

Hydrodynamic relief created by wave processes has the greatest variety. This type of relief is distributed throughout all of the seas and oceans. In the Arctic, however, and especially in seas covered with ice for most of the year, the coastal shallows form under the combined influences of wave action and ice cover. Ice cover sharply weakens the intensity of waves and leads to the accumulation of fine deposits even in the coastal shallows and to the formation of a gently sloping coastal profile on the inner shelf. Such coastal shallows, which evolve not only via wave processes but also with an ice cover, we term an "Arctic type of coastal shallow". They form under the influence of both waves and the ice factor, manifesting a vivid example of modern lithologicalgeomorphological processes in the Arctic coastal zone.

Relic relief created by wave processes (abrasive and accumulative) is represented by ancient coastlines, which are fixed by terrace ledges generated during post-glacial time, as ancient barrier spits, bars and underwater swells flooded and frequently buried under a layer of younger marine deposits. For example, some relic bars are situated on the East Siberian seabed between the river mouths of Kolyma and Indigirka, and within offshore New Siberia and Zhokhov Islands also. Their thickness on the shelf surface ranges from 4-5 to $10-13 \mathrm{~m}$ and they extend from 15-20 to more than $40 \mathrm{~km}$ (Nikiforov 1996).

The tidal relief on the Arctic sea shelves, as well as in all other climatic zones, is represented by extremely modern formations, among which tidal ridges, sandy waves, tidal deltas, troughs, and mud flats are widely distributed. In the southern part of the White Sea Gorlo, they achieve a thickness of $30 \mathrm{~m}$ over the bottom of the largest tidal accumulation ridges, and their length is more than $40 \mathrm{~km}$ at a distance of $10-30 \mathrm{~km}$ between ridges. The characteristic element of accumulative relief on tidal shelves are watts, i.e. regions leveled or dissected to some degree by drain trenches, mud or sandy surfaces, and which are drained periodically by tidal fluctuations in sea level. Destructive tidal forms of relief are over-deepened inter-island channels, trenches in barrierspit channels in lagoons.

Relic relief created under the joint activity of glacial covers and fluvial processes (relic fluvioglacial relief) are represented by channels of sub-glacial snowmelt flows, relatively level surfaces of outwash plains, kames and eskers, and are distributed on shelves of the Northern Atlantic and in parts of the Barents and Kara seas. Channels of sub-glacial snowmelt flows are usually expressed by narrow $\mathrm{V}$-shaped ruts and hollows with incision depths of about $10-50 \mathrm{~m}$ and lengths in the tens of kilometers. Accumulation surfaces of the outwash plains, usually comprised of sand, gravel and pebbles, represent the merged fields of flat cones of fluvioglacial streams and are located in front of end moraine ridges. They are distributed on the surfaces of plateaus in the Greenland, Iceland, and Norway shelves and are also found in the mouths of fiord bays in the northwest portion of the Kola Peninsula.

Relief created by fluvial processes only is represented by relic (paleo-valleys, paleo-deltas, etc.) and modern (river deltas, etc.) forms. Not all relic, eroded valleys were subsequently filled by glacial-marine Quaternary deposits. Some of them persist as flat depressions in the shelf relief, and are often discovered by seismo-acoustic profiling. Quite often these depressions bear dendritic networks almost from the coast up to the shelf edge. In the eastern Eurasian Arctic shelf, in the Laptev, East Siberian and Chukchy seas, the systems of fluvial paleovalleys are etched in regions around the modern mouths or deltas of the Khatanga, Anabara, Lena, Yana, Indigirka, Kolyma, and Amguema rivers and others. These valleys often terminate in paleo-deltas at depths of about $50 \mathrm{~m}$, which were generated in subaquatic conditions as occurs in the Hope paleo-valley (Chukchy Sea), which has a width of about $30 \mathrm{~km}$. In this area, paleo-deltas are found at depths of 50 and $35-40 \mathrm{~m}$ and have been dated with absolute ages of 17,000 and 12,000 years, respectively (Creager and McManus 1967). Paleo-valleys of the Yukon, Anadyr and also Chaplin rivers (as well as others) exist on the Bering Sea shelf, while paleo-valley networks connected with paleochannels of the $\mathrm{Ob}$ and Yenisei rivers occupy the Kara Sea shelf. Recently discovered canyons of the Bering Sea, such as St. Matthew and Middle, with great numbers of tributaries have an erosive origin, too. Middle canyon is distinguished by numerous inflows. Canyon top formation is associated with the paleo-valleys of the 


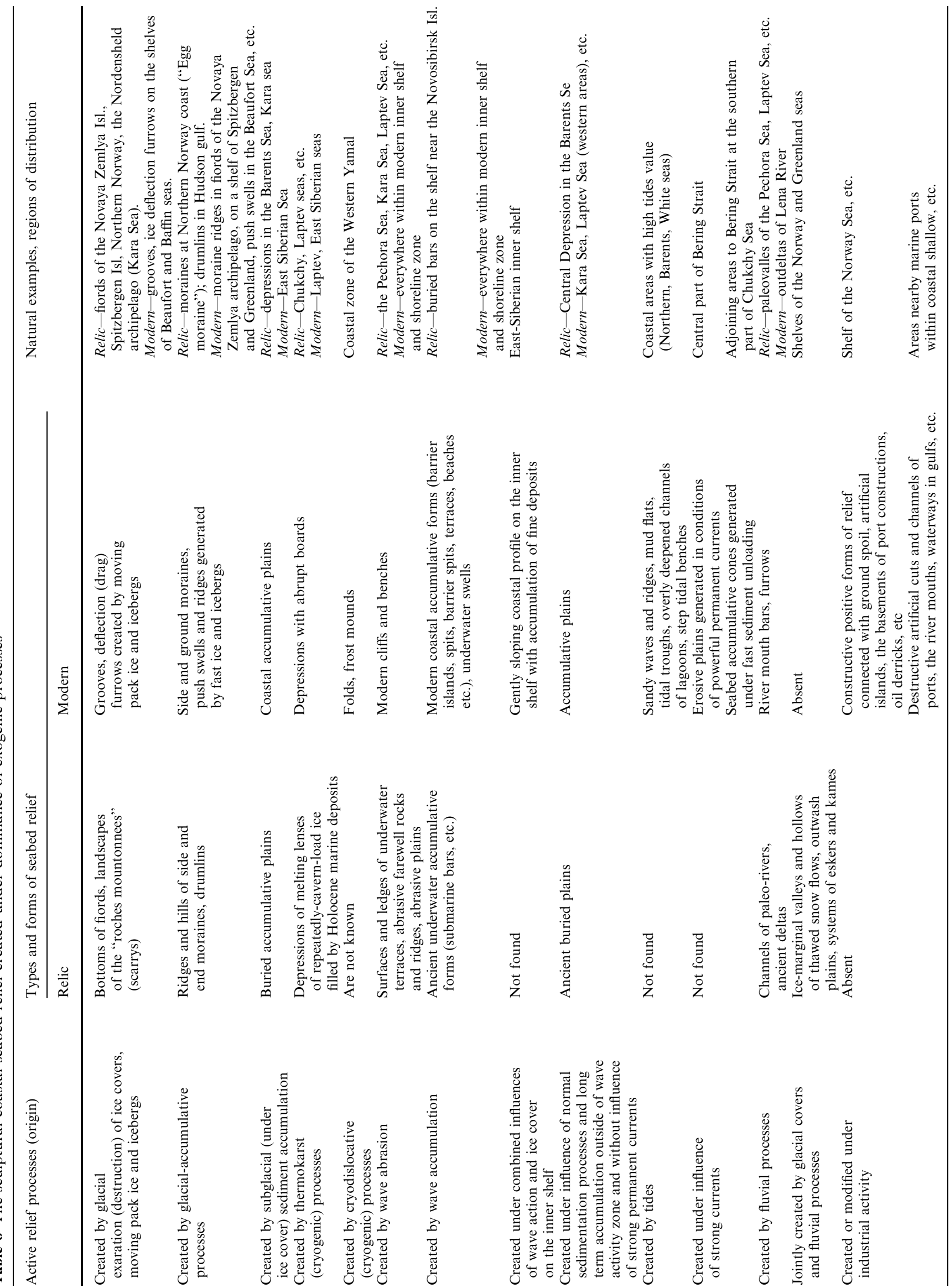


Anadyr and Yukon rivers and with their discharge during the late glacial regression of the ocean (Carlson and Karl 1984). Modern fluvial accumulative forms of shelf relief are shallow locations of delta beaches proximal to the river mouth.

\section{Conclusion}

The modern state of coastal zones is the result of the interaction of complex processes within offshore, shoreline and offshore areas. Under "coast", we understand an "onshore and coastal shallow that has been alternately flooded and exposed since middle Holocene time (climatic optimum)."

The classification offered here is based on scientifically proven representations of morphology, origin and age and geology. We call this kind of approach, which analyzes and determines a complex of interactive factors simultaneously, "morphogenetic".

Among the exogenic and endogenic processes involved, it is possible to allocate active processes, which directly participate in the formation of coastal relief, and passive processes, which predetermine the display of active ones and direct the course of their development. We have developed our understanding that the origin of relief (which formed under the interaction and combination of various modern or paleogeographical processes) is the main factor that created existing coastal morphology.

The development of coasts, their contemporary dynamics and their morphology are closely connected with the development of the offshore coastal zone. Therefore, the principles of coastal morphogenetic classification correspond to the principles of the morphogenetic classification of the Arctic coastal seabed and vice versa. Taking into account the indissoluble association of marine coasts with the coastal offshore, their joint mapping is possible with the use of a single procedure or approach, including one based on GIS technology.

The classification presented here is based on the general approach given in the ACD, which is a project of the International Arctic Science Committee and the International Permafrost Association (IASC Arctic Coastal Dynamics 2001). In addition to the morphological classification suggested by the ACD project, the classification suggested in the present paper considers interactions between coastal morphology and dominant factors (processes) governing coast formation.

Acknowledgments This study is supported by INTAS (grant No. 2001-2332).

\section{References}

Carlson PR, Karl HA (1984) Geology of two large submarine canyons in the Bering Sea. Mar Geol 174:159-179

Coastal Zone Resources Assessment Guidelines (1996) LOICZ reports and studies No. 4, pp 1-101

Creager JS, McManus DA (1967) Bottom sediments data from the continental shelf of the Chuckchi and Bering seas. Washington University Department of Oceanography Tech Rep 135, pp 343-351

Grigoriev MN, Rachold V, Bolshiyanov DYu, Hubberten H-W, Pfeifer E-M, Schirrmeister L, Wagner D (2003) Russian-German Cooperation System Laptev Sea 2000: the expedition LENA 2002. Polar Mar Res 466:350

IASC Arctic Coastal Dynamics (ACD) (2001) Science and Implementation Plan, International Arctic Science Committee, Oslo, April 2001

Ionin AS, Kaplin PA, Medvedev V (1961) Classification of World Ocean shorelines. New studies of seas and inner lakes. Moscow, RAS: 94-108 (in Russian)

Ionin A, Pavlidis Yu, Yurkevich M (1990) Relief of arctic eastern shelf of Russia and its classification. In: Aksenov A (ed) Geology and geomorphology of shelf and continental slope (In Russian). JAD, Moscow Nauka, pp 24-50

Kaplin P, Leont'ev O, Luk'anova S, Nikiforov L (1991) Marine shorelines (in Russian). Misl, Moscow, p 480

Leont'ev O (1956) Classification and shoreline mapping (in Russian). Lomonosov Moscow State University, Geomorphology, p 182

Leont'ev O, Nikiforov L, Saf'anov G (1975) Geomorphology of marine coasts (in Russian). Lomonosov Moscow State University, p 336

McGill IT (1959) Coastal classification maps, a review. In: 2nd coastal geography conference. Coastal Studies Institute, Louisiana

Nikiforov S (1996) The main features of modern sedimentation in the southern part of the East Siberian Sea. Polar Res 212: 89-95

Rachold V (1999) Expeditions in Siberia in 1998. Polar Mar Res 315:268

Rachold V (2000) Expeditions in Siberia in 1999. Polar Mar Res 354:303

Rachold V, Grigoriev MN (2001) Russian-German Cooperation System Laptev Sea 2000: The Expedition LENA 2000. Polar Mar Res 388:135

Rachold V, Brown J, Solomon S (2003) Arctic coastal dynamics (ACD) - a new LOICZ Regional Project. LOICZ Newslett 29, December 2003, 1-5

Richthofen F (1901) Führer für Forschungsreisende. Hannover, Neuntes Kapitel. Beobachtungen an Meeresküsten

Rivkin FM, Koreisha MM, Ivanova NV (2003) The engineeringgeocryological zoning of the Russian Arctic coast for the estimation of hazard caused by the industrial impact. In: Proceedings of the 8th International Conference on Permafrost, 21-25 July 2003, Zurich, Switzerland, AA Balkema Publishers, vol 2. pp 959-964

Schlüter O (1924) Ein Beitrag zur Klassifikation der Küstentypen. "Zeitschrift der Gesellschaft für Erdkunde zu Berlin 8-10

Valentin H (1952) Die Küsten der Erde. Ergänzungsheft 246 zu Petermanns Mitteilungen

Zenkovich VP (1954) Dynamical classification of marine coasts (In Russian). Trudi IORAS 10 